\title{
Legality of the Prespa Agreement Between Macedonia and Greece
}

\author{
Igor Janev \\ Institute of Political Studies, Belgrade, Serbia
}

Email address:

igorjanev@mts.rs

\section{To cite this article:}

Igor Janev. Legality of the Prespa Agreement Between Macedonia and Greece. Journal of Political Science and International Relations. Vol. 2, No. 2, 2019, pp. 50-59. doi: 10.11648/j.jpsir.20190202.13

Received: July 14, 2019; Accepted: August 21, 2019; Published: September 5, 2019

\begin{abstract}
In the present article we examine the legality of the Prespa Agreement, concluded on June 17, 2018, between Macedonia and Greece aiming at resolving their difference over the name of Macedonia. The analysis of the legal validity of Prespa Agreement is carried out by examining the legal basis of United Nations Security Council Resolution 817 (1993) recommending the admission of Macedonia to UN membership but imposing on the applicant a provisional name (pending the settlement of difference over the applicant's name), its legal consistence with the provisions of Vienna Convention on the Law of Treaties (1969) and legality with the general jus cogens norms of International Law enshrined in the UN Charter. It is demonstrated that the UN SC Res.817 (1993) is by itself an ultra vires act and cannot serve as a legal basis for the Prespa Agreement (ex injuria jus not oritur), that the Prespa Agreement violates the provisions of the Vienna Convention on the Law of Treaties (1969) and the peremptory norms of International Law, particularly the principle of self-determination and enters into legal matters that belong stricto sensu to the domain of domestic jurisdiction of Macedonia. For these reasons the Prespa Agreement cannot be considered a legally valid treaty and, consequently, it is null and void.
\end{abstract}

Keywords: Legal ID, Treaty, Agreement, Legality, UN Charter, Law of Treaties, Self-determination, Self-designation, Juridical Personality

\section{Introduction}

The Prespa Agreement (or Prespa Accord, or Treaty of Prespa) between Macedonia and Greece, reached on June 12, 2018 near the Prespa Lake, under the auspices of United Nations relates to the resolution of long-standing "dispute" between the two countries over the name of Macedonia [1]. The official title of the Prespa Agreement reads: "Final agreement for the settlement of the differences as described in the United Nations Security Council resolutions 817 (1993) and 845 (1993), the termination of the Interim Accord of 1995, and the establishment of a strategic partnership between the parties" indicates that the Agreement is based on the accepted (or assumed) legality of the UNSC Resolution 817 (1993). The subject matter of the Prespa Treaty is defined more precisely in the Preamble of the treaty:

"-Resolving the difference pursuant to Security Council resolutions 817 (1993) of 7 April 1993 and 845 (1993) of 18 June 1993, [as well as Article 5 of the Interim Accord of 13 September 1995] in a dignified and sustainable manner, having in mind the importance of the issue and the sensitivities of each Party".

The issue of "difference" (over the name Macedonia) was created by the Greek allegation raised during the process of admission of Republic of Macedonia to UN membership that the name of the applicant implies "territorial claims towards Greece". Despite the fact that Republic of Macedonia has amended its Constitution in 1992, (affirming that it "has no territorial claims against any of neighboring states", and that its borders can only be changed in accordance with the Constitution and "generally accepted international norms"), the Security Council in its Res. 817 (1993) [2], after affirming that "the applicant fulfils the criteria for membership laid down in Article 4 of the Charter of the United Nations" [3], has nevertheless added that the applicant state shall be "provisionally referred to for all purposes within United Nations as 'the former Yugoslav Republic of Macedonia', pending settlement of the difference that has arisen over the name of the state". The second part of the above sentence implies an obligation on the new UN 
member to negotiate over its name with a neighboring state (Greece). Both imposed conditions on Macedonia at the moment of its admission (namely: (i) to accept a provisional name for all purposes within UN and (ii) to negotiate with Greece over its name), defining its UN Membership status, are in sharp violation of Article 2 (1) ("sovereign equality of Members") of UN Charter. Moreover, the provision in SC Res. 817 (1993) that the applicant should negotiate over its name with another state is in violation with Article 2 (7) of the UN Charter prohibiting United Nations to intervene in matter (s) of the domestic jurisdiction of states ("Nothing contained in the present Charter shall authorize the United Nations to intervene in matters which are essentially within the domestic jurisdiction of any state"). The condition (ii) is also in violation with Article 1 (2) of the Charter (the principle of "equal rights and self-determination of peoples" "). The violations of Articles 1 (2), 2 (1) and 2 (7) of the UN Charter in SC Res.817 (1993) represent serious breaches of the Charter. We note that the UN General Assembly admitted Macedonia to UN membership (GA Res. 47/225 (1993)) [4] on the basis of SC Res.817 (1993) (with the addition conditions therein).

\section{Legality of a Treaty and the Grounds of the Prespa Agreement}

The SC Res. 817 (1993), by imposing two additional conditions (obligations) on the applicant state for its admission to UN Membership, (after affirming that the applicant meets "the criteria for membership laid down in Article 4 of the Charter of the United Nations") is in severe conflict with the Advisory Opinion of International Court of Justice (ICJ) of May 28, 1948 [5], related to the conditions required for admission of a state to UN membership, and accepted by the General Assembly in its resolution A/RES/197 (III) on December 8, 1948. The opinion of the International Court of Justice was that "the conditions stated in paragraph 1 of Article 4 must be regarded not merely as necessary conditions, but also as the conditions which suffice" (for admission). Furthermore, it stated: "Nor it can be argued that the conditions enumerated (in paragraph 1 of Article 4) represent an indispensable minimum, in the sense that political considerations could be superimposed upon them, and prevent the admission of an applicant which fulfils them". Hence, the conditions laid down in paragraph 1 of Article 4 of the UN Charter are exhaustive, necessary and sufficient and, if fulfilled appropriately in Security Council's opinion, the applicant state must be unconditionally admitted to UN membership. As mentioned above, this legal interpretation of Article 4 (1) of the Charter by the Court was accepted by the General Assembly in its resolution $\mathrm{A} / \mathrm{RES} / 197$ (III) of December 8, 1948. In view of the accepted Court's interpretation of Article 4 (1) and of its

\footnotetext{
${ }^{1}$ This principle relating to collective human rights as a rule of self-determination is also applicable to the right (s) of State (s). Namely States has a right to selfdetermination.
}

acceptance by the General Assembly in 1948, it follows that the resolutions SC Res. 817 (1993) and GA Res. 47/225 (1993) with the additional conditions imposed on Macedonia at its admission to UN membership are in violation with Article 4 (1) of the Charter as a legal norm. ${ }^{2}$ As mentioned above, the introduction of the additional conditions (i) and (ii) for the admission of Macedonia to UN membership was based on the Greek allegation that the name of the applicant "implies territorial claims" were reflected in the wording of both resolutions as "difference over the name". However, according to the international law no state has an exclusive right over a name and that the "Greek demand that Macedonia change its name has no basis in the international law and practice" [6]. Indeed, as argued by Janev [7-9], based on the principle of separability of domestic and international jurisdictions, the name of a state, which is subject to that state's domestic jurisdiction, does not create international legal rights for that state, nor does it impose legal obligations on other states. Clearly, the name per se does not have a direct impact on the territorial rights of states. ${ }^{3}$ Therefore, the Greek allegation that the name of the applicant implies "territorial claims" has no legal significance. Interference with matters that are essentially within the domestic jurisdiction of a state, such as the choice of state's name, is also incompatible with Article 1 (2) of the UN Charter ("selfdetermination of peoples"). Article 2 (7) of the Charter explicitly extends the validity of this legal norm to the United Nations themselves. It appears, therefore, that the Greek opposition to the admission of Macedonia to UN membership under its constitutional name and the intervention of the UN Security Council in the matters related to the name of the applicant state, are inconsistent with the Charter [3, 7].

The inherent right of a state to have a name can be derived from the necessity that a juridical person must have a legal identity. ${ }^{4}$ In absence of such identity, the juridical person, such as a state, could to a large extent loose its capacity to interact with other juridical persons (e.g. conclude agreements, etc.) and independently enter into and conduct its external relations. The name of a state is, thus, an essential element of its juridical personality and of its statehood. ${ }^{5}$ The principles of sovereign equality of states and the inviolability of their juridical personality lead to the conclusion that the choice by a state of its own name is a basic, inherent (natural) right of the state. This right is not alienable, divisible or transferable. It is an essential part of the right to 'selfdetermination' (determination of one's own legal identity), i.e. it belongs to the domain of jus cogens norms. External interference with this basic right is inadmissible. It is also

\footnotetext{
${ }^{2}$ By definition, a legal norm may not contain indefinite set (or number) of conditions or obligatory legal elements.

${ }^{3}$ It leads us to another important principle that two or more states could not have a "dispute" or a "difference" over the State name (legal ID), and that such so-called "dispute (s)" are (were) groundless.

${ }^{4}$ A legal identity (or a name) of a State by definition is an essential element of both internal (domestic) and international legal personality of a State, and may not be subject of any intervention (particularly not by external acts, such as agreements or resolutions).

${ }^{5}$ International legal personality in our view is an essential element of a Statehood.
} 
obvious that if such an external interference with the choice of the name of a state would be allowed, even through a negotiation process, it might easily become a legally endorsed mechanism for interference in the internal and external affairs of that state, i.e. a mechanism for degradation of its political independence (described in the Article 2 (4) of the Charter). From these reasons, the choice by the state of its own name (legal identity) must be considered as an inherent right of the state that stricto sensu belongs to the domain of its domestic jurisdiction. In exercising this right, the states have, therefore, a complete legal freedom. This freedom may in practice be constrained only by considerations of avoidance the overlap of legal identities of two (or more) international juridical persons. (The province 'Macedonia' in Northern Greece is, however, not an international juridical person).

The imposition of two additional conditions on Macedonia at the time of its admission to membership to United Nations (to accept a provisional name for use within the UN system and negotiate with Greece over its name), outside those exhaustively enumerated in Article 4 (1) of the Charter, represents a breach of the Charter provisions and, therefore, are an ultra vires act. They also violate Article 1 (2) of the Charter (the principle of "equal rights and self-determination of peoples"). It is important to note that these conditions transcend the time (a moment) of the admission act and define a membership status which is also in violation with the provisions of paragraphs 1 and 7 of Article 2. The condition for acceptance of a provisional name is also in violation with Article 83 of the "Vienna Convention on the Representation of States in their Relations with the International Organizations of Universal Character" of March 14, 1975 [10], dealing with the issue of non-discrimination of states in these relations.

The derogated UN membership status of Macedonia and the breaches of the UN Charter provisions by the resolutions SC Res. 817 (1993) and GA Res. 47/225 (1993), as well as their juridical redress, have been discussed in several literature papers [11]. The legal responsibility of the United Nations for violation of Charter's provisions stems from the UN duty to respect the basic rights of the states (either as applicants or UN member (s)), which are protected by the principles of international law enshrined in the mentioned articles of the Charter. The juridical redress of the UN Charter violations in SC Res. 817 (1993) and GA Res. 47/225 (1993) resolutions can only be carried out through the International Court of Justice by reaffirming its own advisory opinion of May 28, 1948 and recalling the General Assembly resolution A/RES/197 (III) of December 8, $1948^{6}$.

\footnotetext{
${ }^{6}$ Advisory Opinion, 1948 ICJ view of the Court was elaborated specifically and in depth by Judge Alvarez who stated that, having regard to the nature of the universal international society, the purposes of the UN and its mission of universality, it must be held that all States fulfilling the conditions required by Article 4 of the Charter have a right to membership in that Organization and the exercise of this right cannot be blocked by the imposition of other conditions not expressly provided for by the Charter, by international law or by a convention, or on grounds of a political nature.
}

The condition regarding negotiations with Greece ("speedy settlement of the difference over the name") needs a more detailed analysis. It is an obligation imposed on Macedonia whose fulfillment depends on another country and is, therefore, outside of its control. ${ }^{7}$ The obligation for "the settlement of the difference over the name" is carried only by one of the parties involved, while the other party has a full freedom and control over the negotiating process. ${ }^{8}$ Indeed, in the course of negotiations over 25 years, mediated by a UN Special Representative, Greece has been repeatedly obstructing the "negotiations" by ever-expanding its demands. In later years of negotiating process the Greek demands started to include more and more matters which are strictly within the domain of domestic jurisdiction of Macedonia (significant changes to the Constitution, demands relating to the use of Macedonian language and redefinition of other elements of the national identity) and will be discussed in more detail in the next Section. Here we only note that these demands are completely outside of the initial legal frame of the subject of negotiations, formulated by the SC Res. 817 (1993) and in the latest stage of the negotiation process took the form of an ultimatum. ${ }^{9}$

Thus, the illegal conditions imposed on Macedonia for its admission to UN membership relating to the provisional name of the state and the "settlement of the difference" over its name generated a serious long-term "problem" in the relations between Macedonia and Greece, threatening Macedonian people to lose their national identity. ${ }^{10}$

It should be noted that before its admission to the UN membership in 1993, Macedonia had been recognized by its constitutional name "Republic of Macedonia" by 30 sovereign states. As a member of the United Nation its legal personality has been given a provisional denomination 'The Former Yugoslav Republic of Macedonia" for use within the UN system. However, due to the authority of the UN "recognition" many countries and international organizations have "recognized" it with the UN denomination. It is further worth noting that many countries have recognized it by its constitutional name, neglecting the UN denomination. The total number of UN member states which have recognized Macedonia by its constitutional name before the conclusion

\footnotetext{
${ }^{7}$ See Admission of a State to the United Nations (Charter, Art. 4), Advisory Opinion, 1948 ICJ (May 28), ICJ Rep. at 63 (If additional conditions were permitted paragraph 1 of Article 4 would cease to be a legal norm). It follows that the conditions laid down in paragraph 1 of Article 4 are not only necessary, but also sufficient conditions for admission to membership in the United Nations. Conditioning it with previous recognition is apparently external to the scope of that set (See case of Portugal's admission to UN, candidate blocked by the USSR on the mutual pre-recognition demands).

${ }^{8}$ It should be noted that both additional conditions were of a political nature and relates to the non-recognition of one state by the other one.

${ }^{9}$ UNSC Res. 817 relates only to the "name issue", but in the process of obtaining a date for starting negotiations for EU and NATO accessions, Greek demands expanded to all aspects of national identity erga omnes (demanding fundamental ID changes in the Constitution of other state)

${ }^{10}$ According to erga omnes conditions imposed by Greece, Constitution had to be changed according to the ID modifiers contained in the Prespa Agreement, despite of the explicit provision in the Macedonian Constitution providing treaties to be in accordance with the Constitution (and not vice versa).
} 
of Prespa Agreement was 134 [12]. This number by itself (69.4\% of the total UN membership) can serve as an indication of the baselessness of legal, political and historic arguments of Greece for the change of constitutional name of Macedonia, as well as of the illegality of related UN SC 817 (1993) and GA 47/225 (1993) resolutions. As mentioned earlier, there is no legal basis in the international law and practice for the Greek demands [6]. ${ }^{11}$ The Security Council was apparently completely ignorant of this fact and, more importantly, of the legal interpretation of Article 4 (1) of the Charter given in the 1948 Advisory Opinion of the International Court of Justice, another principal organ of the United Nations. Irrespective whether a result of ignorance or politically motivated inclination, the additional conditions imposed on Macedonia at its admission to UN membership represent a severe violation of the legal norms enshrined in the UN Charter Articles 1 (2), 4 (1), 2 (1, 7), producing dramatic negative consequences for its membership status and its external legal and political relations. In conclusion, UNSC Res. 817 clearly represents an ultra vires act of the United Nations and violates the general principles International Law (the jus cogens norms). For these reasons, the UNSC Res. 817 (1993), as well as the related GA 47/225 (1993), cannot be considered as legally valid documents on the basis of which another legally valid document can be created (the legal principle "ex injuria, jus non oritur"). Similar conclusion can be derived for the UNSC Res. 845 (1993) [13], "urging" parties to continue the negotiations over the name of the member state. ${ }^{12}$

\section{Discussion Related to the Prespa Agreement and the Vienna Convention on the Law of Treaties}

In the Preamble of the Vienna Convention on the Law of treaties [14] it is stipulated that the State Parties of the Convention are "having in mind the principles of international law embodied in the Charter of United Nations, such as the principles of equal rights and self-determination of peoples, the sovereign equality and independence of States, of non-interference in the domestic affairs, [....], and of universal respect for, and observance of, human rights and fundamental freedoms for all".

In the Preamble of Prespa Agreement is also stipulated that the Parties of the Agreement are:

-"Guided by the spirit and principles of democracy, respect for human rights and fundamental freedoms, and dignity", and

-"Abiding by the provisions of the Charter of the United Nations"13

However, already in the first sentence of the Preamble of

\footnotetext{
${ }^{11}$ The name of a State also cannot be subject to theft or falsification.

${ }^{12}$ States also cannot be subjected to (endless) negotiations over their legal identity (ID), since an ID cannot be imposed on a State and State as a legal person cannot be deprived form the legal ID (or its name).

${ }^{13}$ Ibid. Prespa Agreement, Preamble
}

Prespa Agreement the Parties of the Agreement are treated as un-equal: the First Party is identified by its constitutional name (Hellenic Republic), while the Second Party is identified as the state "which was admitted to the United Nations in accordance with the United Nations General Assembly resolution 47/225 of 8 April/1993". ${ }^{14}$ This unequal representation of the Parties of the treaty already in its Preamble is a violation of the principle of "sovereign equality" 15 of states and inobservance of the dignity of the Second Party. This un-equal position of the Parties remains throughout the text of the Treaty.

The Prespa Treaty contains three parts of which only the first part (containing eight articles) deals with the name issue; the other two regulate matters of bilateral character (economic, political and cultural relations and establishment of a "strategic partnership").

In paragraph 2 of Article 1, "The Parties recognize as binding the outcome of the negotiations that have taken place under the auspices of the United Nations, to which both Parties have been committed pursuant to the United Nations Security Council resolutions 817 (1993) and 845 (1993) [as well as the Interim Accord of 1995] [15]". We note that SC Res.845 (1993) "urges the parties to continue their efforts to arrive at a speedy settlement of the remaining issues between them". The wording "remaining issues" in the interpretation of the First Party of Prespa Agreement does not mean only "difference over the name" but extends to matters of national identity, state language, constitution and even the internal administrative system and rules. This Greek interpretation of the provisions of SC Res.845 (1993) is apparently fully arbitrary and goes far beyond the original scope of the "negotiations" for "settlement of difference over the name" as defined by the SC Res. 817 (1993) and GA 47/225 (1993) (which, as already discussed earlier, violate the UN Charter). Nevertheless, this Greek interpretation of SC resolutions 817 (1993) and 845 (1993) is thoroughly reflected in all eight articles of Part I of the Prespa Agreement. The tone and the wording of the provisions of this part of the Agreement are reminiscent to those of a peace treaties dictated by the party winning the war to the one that had lost the war. This can be illustrated by the text of paragraph 3 of Article 1 of the Agreement, where the unusual treaty obligations of the Second Party are enumerated:

3. "Pursuant to those negotiations the following have been mutually accepted and agreed:

a) The official name of the Second Party shall be the "Republic of North Macedonia", which shall be the constitutional name of the Second Party and shall be used erga omnes, as provided for in this Agreement. The short name of the Second Party shall be "North Macedonia".

b) The nationality of the Second Party shall be Macedonian/citizen of the Republic of North

\footnotetext{
${ }^{14}$ Ibid.

${ }^{15}$ Sovereign equality in the UN Charter also covers basic principle of the juridical equality as the general jus cogens norm (all are equal under the law).
} 
Macedonia, as it will be registered in all travel documents.

c) The official language of the Second Party shall be the "Macedonian language", as recognized by the Third UN Conference on the Standardization of Geographical Names, held in Athens in 1977, and described in Article 7 (3) and (4) of this Agreement.

d) The terms "Macedonia" and "Macedonian" have the meaning given under Article 1 (7) of this Agreement.

e) The country codes for licenses plates of the Second Party shall be NM or NMK. For all other purposes, country codes remain $\mathrm{MK}$ and $\mathrm{MKD}$, as officially assigned by the International Organization for Standardization ("ISO").

f) The adjectival reference to the State, its official organs, and other public entities shall be in line with the official name of the Second Party or its short name, that is, "of the Republic of North Macedonia" or "of North Macedonia". Other adjectival usages, including those referring to private entities and actors, that are not related to the State and public entities, are not established by law and do not enjoy financial support from the State for activities abroad, may be in line with Article 7 (3) and (4). The adjectival usage for activities may be in line with Article 1 (7) (-3) and (-4). This is without prejudice to the process established under Article 1 (3) (h) and compound names of cities that exist at the date of the signature of this Agreement.

g) The Second Party shall adopt "Republic of North Macedonia" as its official name and the terminologies referred to in Article 1 (3) through its internal procedure that is both binding and irrevocable, entailing the amendment of the Constitution as agreed in this Agreement.

h) In relation to the above mentioned name and terminologies in commercial names, trademarks and brand names, the Parties agree to support and encourage their business communities to institutionalize a sincere, structured and in good faith dialogue, in the context of which will seek and reach mutually accepted solutions on the issues deriving from the commercial names, the trademarks, the brand names and all relevant matters at bilateral and international level. For the implementation of the above mentioned provisions, an international group of experts will be established consisting of representatives of the two States in the context of the European Union ("EU") with the appropriate contribution of the United Nations and ISO. This group of experts shall be established within 2019 and conclude its work within three years. Nothing in Article 1 (3) (h) shall affect present commercial usage until mutual agreement is reached as provided in this subsection". 16

It is obvious from the above that the First Party essentially dictates the treaty provisions, while the Second Party needs

\footnotetext{
${ }^{16}$ Ibid. Prespa Agreement, Article 1
}

only to accept them. The inequality of Treaty Parties is obvious, despite of their equal legal status under the International Law. The Second Party obviously has a subordinate position with respect to the First one. Greece dictates even official names in the "Republic of North Macedonia" and usage by government and semi-government bodies. $^{17}$

The core provisions b) and c) of paragraph 3 are essentially beyond the scope of the subject of the Agreement defined by SC Res. 817 ("settlement of difference" over the name) and relate (s) to the matters of national identity and language. As mentioned in sub-paragraph (3-f) above the meaning of noun "Macedonia" and adjective "Macedonian" is provided by the provisions of Article 7 the first three paragraphs of which read:

1. The Parties acknowledge that their respective understanding of the terms "Macedonia" and "Macedonian" refers to a different historical context and cultural heritage.

2. When reference is made to the First Party, these terms denote not only the area and people of the northern region of the First Party, but also their attributes, as well as the Hellenic civilization, history, culture, and heritage of that region from antiquity to present day.

3. When reference is made to the Second Party, these terms denote its territory, language, people and their attributes, with their own history, culture, and heritage, distinctly different from those referred to under Article $7(2) .^{18}$

The provisions 2 and 3 deprive the terms "Macedonia" and "Macedonian" from their general meaning, framing them within a historic, cultural or regional context. This is a severe derogation of Macedonian national identity and Macedonian language; it represents a flagrant negation of the rights to self-identification of the national identity, culture and language of Macedonian minority in Greece and in other countries. Like the state name (or ID), the identity of a people or a nation, its culture and language are inherent, indivisible, non-transferable and non-alienable. Therefore, the Articles 1 (3-f) and Article 7 are in violation with the general peremptory norms of International Law, including those related to the rights minorities. ${ }^{19}$

In the remaining paragraphs 4-13 of Article 1 the implementation of the provisions of Article 1 (3) are stipulated, again in an ultimate form, with the First Party

\footnotetext{
${ }^{17}$ That covers even bodies that do not enjoy financial support from the State, and that includes private media (which, by definition should be free from any state or external intervention).

${ }^{18}$ Ibid. Prespa Agreement, Article 7. Basically, Greece won exclusivity for these terms worldwide, and Second Party may use such restricted terms in the described manner only locally and under the controlled conditions.

${ }^{19}$ Apparently with the Agreement, Macedonian government gave up from protection on their minority in Greece (see more about that basic right in UN Declaration on the Rights of Persons Belonging to National or Ethnic, Religious and Linguistic Minorities (1992), for example Article I (1) that states: "States shall protect the existence and the national or ethnic, cultural, religious and linguistic identity of minorities within their respective territories and shall encourage conditions for the promotion of that identity.")
} 
playing the oversighting role.

4. Upon signing this Agreement, the Parties shall take the following steps:

a) The Second Party shall, without delay, submit the Agreement to its Parliament for ratification.

b) Following ratification of this Agreement by the Parliament of the Second Party, the Second Party shall notify the First Party that its Parliament has ratified the Agreement.

c) The Second Party, if it decides so, will hold a referendum.

d) The Second Party shall commence the process of constitutional amendments as provided for in this Agreement.

e) The Second Party shall conclude in to the constitutional amendments by the end of 2018 .

f) Upon notification by the Second Party of the completion of the above mentioned constitutional amendments and of all its internal legal procedures for the entry into force of this Agreement, the First Party shall promptly ratify this Agreement.

5. Upon entry into force of this Agreement, the Parties shall use the name and terminologies of Article 1 (3) in all relevant international multilateral and regional Organizations, institutions and fora, including all meetings and correspondence, and in all their bilateral relations with all Member States of the United Nations.

6. In particular, immediately upon entry into force of this Agreement, the Second Party shall:

a) Notify all international, multilateral and regional Organizations, institutions and fora of which it is a member of the entry into force of this Agreement, and request that all those Organizations, institutions and fora thereafter shall adopt and use the name and terminologies referred to in Article 1 (3) of this Agreement for all usages and purposes. Both Parties shall also refer to the Second Party in accordance with Article 1 (3) in all communications to, with, and in those Organizations, institutions and fora.

b) Notify all Member States of the United Nations of the entry into force of this Agreement and shall request them to adopt and use the name and terminologies referred to in Article 1 (3) of this Agreement for all usages and purposes, including in all their bilateral relations and communications.

7. Upon entry into force of this Agreement, and subject to provisions under Articles 1 (9) and (10), the terms "Macedonia", "Republic of Macedonia", "FYR of Macedonia", "FYR Macedonia" in a translated or untranslated form, as well as the provisional name "the former Yugoslav Republic of Macedonia" and the acronym "FYROM" shall cease to be used to refer to the Second Party in any official context.

8. Upon entry into force of this Agreement and taking into account its Article 1 (9) and (10), the Parties shall use the name and terminologies of Article 1 (3) for all usages and all purposes erga omnes, that is, domestically, in all their bilateral relations, and in all regional and international Organizations and institutions.

9. Upon entry into force of this Agreement, the Second Party shall promptly in accordance with sound administrative practice take all necessary measures so as the country's competent Authorities henceforth use internally the name and terminologies of Article 1 (3) of this Agreement in all new official documentation, correspondence and relevant materials.

10. As regards the validity of already existing documents and materials issued by the Authorities of the Second Party, the Parties agree that there shall be two transitional periods, one "technical" and one "political":

a) The "technical" transitional period shall relate to all official documents and materials of the Public Administration of the Second Party for international usage and to those for internal usage that may be used externally. These documents and materials shall be renewed in accordance with the name and terminologies as referred to in Article 1 (3) of this Agreement within five years from the entry into force of this Agreement, at the latest.

b) The "political" transitional period shall relate to all documents and materials exclusively for internal usage in the Second Party. The issuance of the documents and materials falling under this category in accordance with Article 1 (3) shall commence at the opening of each EU negotiation chapter in the relevant field, and shall be finalized within five years thereof.

11. Procedures for the prompt amendment of the Constitution of the Second Party, In order to fully implement the provisions of this Agreement, shall commence upon ratification of this Agreement by Its Parliament or following a referendum, if the Second Party decides to hold one.

12. The name and terminologies as referred to in Article 1 of this Agreement shall be incorporated in the Constitution of the Second Party. This change shall take place an bloc with one amendment. Pursuant to this amendment, the name and terminologies will change accordingly in all articles of the Constitution. Furthermore, the Second Party shall proceed to the appropriate amendments of Its Preamble, Article 3 and Article 49, during the procedure of the revision of the Constitution.

13. In the event of mistakes, errors, omissions in the proper reference of the name and terminologies referred to in Article 1 (3) of this Agreement in the context of international multilateral and regional Organizations, institutions, correspondence, meetings and fora, as well as in all bilateral relations of the Second Party with third States and entities, either of the Parties may request their immediate rectification and the avoidance of similar mistakes in the future. ${ }^{20}$

\footnotetext{
${ }^{20}$ Ibid. Prespa Agreement, Article I, see also provisions in Article 7. Not only official documents and materials of the Public Administration were placed under control, but Second Party shall proceed to the appropriate amendments of its Constitutional Preamble, and even further in Article 3 and Article 49 of the Constitution (relating to non-interference), during the procedure of the revision of the Constitution. And finally country will have to inform all UN members and UN
} 
It should be noted that the implementation of the provisions of Article 1 (3) requires more amendments of the Constitution of the Second Party (including Preamble), paragraphs 4 (d, e), 11 and 12, and the use of the new name, adjectives and related terminologies shall be used for all proposes erga omnes (i.e. internally and externally) by both Parties (Article 1 (8)).

The provisions of Article $1(3-a,-b,-c)$ related to the name, national identity and the language, respectively, of the Second Party, and the provisions of Article 7 (1-5) providing historic, territorial and cultural restrictions to their use, and thereby severely derogating their meaning, as well the provisions of Articles 1 (4), 1 (11) and 1 (12) imposing explicitly revision and amendments to the Constitution of the Second Party, are obviously in conflict with the peremptory norms of International Law and Article 53 and Article 64 of the Vienna Convention on the Law of Treaties (1969). For this reason the Prespa Agreement can be considered as null and void. Its implementation is also problematic under the Article 61 of the Vienna Convention (Supervening impossibility of performance). ${ }^{21}$

Perhaps the most unusual, and apparently outside the legal framework of International Law, is the establishment by the Article 8 (5) of Prespa Agreement, "on a parity basis, a Joint Inter-Disciplinary Committee of Experts on historic, archaeological and educational matters, to consider the objective, scientific interpretation of historical events based on authentic, evidence-based and scientifically sound historical sources and archaeological findings. The Committee's work shall be supervised by the Ministries of Foreign Affairs of the Parties in cooperation with other competent national authorities. It shall consider and, if it deems appropriate, revise any school textbooks and school auxiliary material such as maps, historical atlases, teaching guides, in use in each of the Parties, in accordance with the principles and aims of UNESCO and the Council of Europe. To that effect, the Committee shall set specific timetables so as to ensure in each of the Parties that no school textbooks or school auxiliary material in use.the year after the signing of this Agreement contains any irredentist/revisionist references. The Committee shall also study any new editions of school textbooks and school auxiliary material as provided for under this Article. The Committee shall convene regularly, at least twice a year, and shall submit an Annual Report on its activities and recommendations to be approved by the Highlevel Cooperation Council, as to be established pursuant to Article 12."22

This provision again is far from the legal standards of sovereign rights of states, provides a mechanism for permanent interference in the internal affairs of other state. There are only a few articles on this matter. ${ }^{23}$

about new ID including the terminologies referred to in Article 1 (3) of this Agreement.

${ }^{21}$ Ibid. Convention, Art. 61.

${ }^{22}$ Ibid. Prespa Agreement, Article 8

${ }^{23}$ G. S. Davkova, On The "Prespa Agreement" and Beyond, UMD, see: http://umdiaspora.org/2019/01/28/on-the-prespa-agreement-and-beyond-by-

\section{The Political and Legal Context of the Prespa Agreement and the Grounds for Termination of the Treaty}

In order to understand how the negotiations regarding the "difference over the name" imposed on Macedonia by SC Resolutions 817 and 845 resulted in change of its constitutional name for use erga omnes, severe derogation of its national identity, culture and language (Articles 1 (3), 7 $(1-5), 8(3,5)$ of the Agreement) and to agree with an obvious interference of the First Party in matters from the domain of its domestic jurisdiction (cf. Articles 1 (4), 1 (11), 1 (12), 8 (5)) one should take into account the foreign-political goals of Republic of Macedonia, proclaimed soon after gaining its independence: membership to European Union and NATO. Membership to EU and NATO requires consent of all members of the corresponding organization. As member of both organizations, Greece was openly conditioning its consent to the accession of Macedonia to EU and NATO with resolving the name issue. On the other hand, the political background in the years preceding the conclusion of Prespa Agreement was such that both EU and NATO expressed strong interest to speed up the resolution of the GreekMacedonian name issue, motivations being mainly of security nature. The pressure on both counties by the officials of both organizations, but also by diplomatic representatives of the major NATO countries, was manifestly strong. Macedonia was receiving promises for prompt start of the accession negotiations with EU and prompt invitation to NATO membership. Indeed, after the ratification of the Agreement by the Macedonian Parliament on 20 June, 2018, (with 69 MP's voting in favor) and after the Greek Ministry of Foreign Affairs informed the EU and NATO, on 25 June, 2018, that Greece no longer objects the accession of Macedonia to these two organizations under its new name Republic of North Macedonia, the EU approved on 27 of June the start of accession negotiations in 2019, and on 11 of July, 2018, NATO issued an invitation to Macedonia for membership.

The 25 year long period of negotiations of Macedonia and Greece is an indication of the sensitivity of citizens of both countries to the name issue. Any step of negotiations toward its resolution was associated by massive protests in one (or both) of the countries. Reaching a solution of the name issue was perceived as a grave decision and betrayal of national interests by some of the political parties in both countries. Given the strong economically motivated aspiration of Macedonia to join EU and the firm stand of Greece to block this without any benefit for itself, a "historic compromise" seemed to be unavoidable. This compromise was the Prespa Agreement which, as argued above, violates the peremptory norms of International Law. As the gravity of the name issue ("change of the name"), in view of negotiating parties, was considered higher in the Second

professor-dr-gordana-siljanovska-davkova// 
Party, the Prespa Agreement provided for a referendum in the Second Party (Articles 1 (4, c) and 1 (11)) after the ratification of the Agreement by its Parliament.

The referendum on Prespa Agreement was held on September 30, 2018, but the turnover was only $36.7 \%$, far short from that required by the Constitution, 50\%. On October 15, the Parliament of Macedonia started the debate on the name change and constitutional reform and after some political wrangling the Parliament on January 11, 2019 has completed the legal implementation of Prespa Agreement and approved the constitutional changes renaming the country to North Macedonia with a two-thirds parliamentary majority (81 PMs) as required by the Constitution. The president of the Republic of Macedonia, however, refused to sign the bill. Contrary to the Constitution of Republic of Macedonia [16] the bill was signed by the Speaker of the Parliament Mr. Zhaferi instead. We mention that the president if the Republic refused to sign also the Prespa Agreement qualifying it as unconstitutional [17].

The ratification of Prespa Agreement by the Greek Parliament took place on 25 of January, 2019, with 153 votes in favor, 146 votes against and 1 abstention. The closeness of the votes "in favor" and "against" reflects the strong division of Greek public opinion about the Agreement. Similarly, a public opinion poll done for the Sitel TV channel in North Macedonia on February 2019 showed that $44.6 \%$ of respondents were positive, and $45.6 \%$ were negative toward the Prespa Agreement [18]. The almost equal split of the population in both countries for "pro" and "contra" the Agreement, indicates its fragility and possible breakup of the Agreement in the (near) future by either of the parties. The likelihood of such event stems from the fact that the party coalitions, having majority in the Greek and Macedonian Parliament, are not very viable, and small changes in the political equilibrium in either country could affect the "pro" and "contra" ratio in that country Parliament. Indeed, the change of parliamentary majority in Greece happened on $7^{\text {th }}$ of July 2019 while similar outcome is expected in Macedonia at the next parliamentary elections in year 2020. The major parties, the New Democracy in Greece and the VMRODPMNE in Macedonia, are both fiercely against the Prespa Agreement in its present form. The right-wing party "New Democracy" in Greece won the elections with an absolute majority and, thus, it is already empowered to take steps toward withdrawal from the Agreement or for making changes that are unacceptable for Macedonia.

The leaders of Macedonian opposition party VMRODPMNE, currently having 51 seats in the parliament, have already declared their intention to take unilateral legal actions for termination of the Agreement, once their coalition gets the majority in the parliament. That could easily take place if the EU does not start the accession process with Macedonia by the end of 2019, as approved at the EU summit on June $27,2019 .^{24}$

\footnotetext{
${ }^{24}$ See also After Prespa: Could the North Macedonia name agreement fall, ECFR, https://www.ecfr.eu/article/commentary_after_prespa_could_the_north_macedoni
}

The strongest legal argument of Macedonia for unilateral withdrawal from the Prespa Agreement or for its termination would be its violation of Article 53 of the Vienna Convention on the Law of Treaties ("A treaty is void if at the time of its conclusion, it conflicts with peremptory norms of international law.") [10] As discussed earlier the right to selfdetermination of nation's name and identity represents such a norm $^{25}$. Moreover, the legal basis of the Prespa Agreement, the SC resolutions 817 and 845 , is in violation with the UN Charter Articles $1(2,7), 2$ (1) and 4 (1) and makes the Agreement a priory unlawful according to the general legal principle ex injuria jus non oritur. Furthermore, the provisions of Prespa Agreement explicitly enter into the domain of domestic jurisdiction of Macedonia and are in conflict with the basic norms of international law, and establish instruments for permanent intervention into internal affairs of the country (Articles 1, 7 and 8), derogating particularly its cultural rights. Finally, Prespa Agreement was signed by the Minister of Foreign Affairs, and not by the President (as required by Article 119 of the Macedonian Constitution $^{26}$ ), and the ratification act was not signed by the President (but by the Speaker of the Parliament), so Macedonia can also revoke Article 46 of the Vienna Convention $^{27}[14]$ as a ground for termination of the Treaty.

\section{Conclusions}

In the present article we have examined the legality of the Prespa Agreement concluded between Macedonia and Greece on June 12, 2018, aiming at resolving the 25 year long dispute between the two countries over the name of Macedonia. We have analyzed the legal basis of the UN SC Resolutions 817 (1993) and 845 (1993) in which the name dispute was imposed on Macedonia as a condition during its admission to UN membership, together with the condition to accept a provisional name "The Former Yugoslav Republic of Macedonia" for use within the system of United Nations. We have argued that imposing of additional in SC Res. 817 conditions to an applicant state, after affirming that the applicant fulfills the admission conditioned laid down in Article 4 (1) of the UN Charter is in severe violation with the Advisory opinion of the International Court of Justice of 28 May 1948, of 1948, accepted by the General Assembly Resolution 197/III of 1948. In view of these two UN documents the SC Res. 817 (1993) is in breach with the UN Charter Articles 1 (2), 2 (1), 2 (7) and 4 (1), the first two belonging jus cogens norms of international law. The SC Res.

\footnotetext{
a name agreement fall apart

${ }^{25} \mathrm{~A}$ link between the name of the State and national identity (as a collective human right) lies in the category of legitimacy that means original sovereign people's will and consent to freely refer to itself and to self-identify itself or themselves as a people or as a nation, in accordance with the basic principle of sovereign people's will (i.e. popular sovereignty).

${ }^{26}$ According to Article 119 of the Constitution of the Republic of Macedonia, political treaties of such general nature can be concluded only by the president of state.

${ }^{27}$ Ibid. Vienna Convention (1969), Article 46 (Provisions of internal law regarding competence to conclude treaties)
} 
817 is therefore an ultra vires act, breaching the peremptory norms of international law and cannot serve as legal basis for the Prespa Agreement (according to general legal principle ex injuria jus non oritur).

The Prespa Agreement is by itself in conflict with jus cogens norms of international law and enters in legal matters that belong stricto sensu in the domain of the domestic jurisdiction of the other party. Its provisions even provide mechanisms for permanent intervention into internal and external affairs of the Second Party, derogating its human (dignity) and cultural rights. Therefore, the Prespa Agreement violates Article 53 of the Vienna Convention on the Law of Treaties.

As was observed in the case of Macedonia, the Agreement could not be reached until one country (in this case Macedonia) agreed to change the most sensitive parts of its Constitution relating to the Sovereign people's will and original consent on identity, basically denying legitimacy of people's will to be referred and self-identified as Macedonians. Therefore we can conclude that even in the case when a government gives its consent on identity treaty, the inherent right for self-determination that by definition covers both national and the State legal identity, precludes validity of such arrangement related to limitation of selfdesignation. An agreement based on the "difference" (wording like in UNSC Res. 817) or a "dispute" related to the State's identity or a national identity could not legally exist under the present norms of International Law. Such a treaty does not have a valid legal subject, because the inherent right of self-identification as part of a jus cogens norm related to self-determination depends solely on the original sovereign will of the people (not a government, nor representatives of people could re-define it). Also it should be noted that "national identity" and the legal ID of the State are the same one in the International Law, and that the State identity always covers erga omnes criterion (for every use, domestic and international) since identity of the State as an international legal person is the same one as the legal identity of the State as a domestic legal person in the internal legal (or the Constitutional) order of the State.

Hence, let's summarize the relevant international legal principles that could be used for the basic conclusions on the legal nature of the Prespa Agreement. As we have already seen in the textbook on International Law, the first principle applicable to the Macedonian case is that States have no exclusive rights over the name of the State. In the "security context" that was artificially created and added to the text of UNSC Res. 817, this principle of no exclusive rights is of special importance, since Greece advocated that candidate for UN tried to take a name of the wider region, and that such situation created "security concerns". In the light of the upper basic principle, the State identity of Republic of Macedonia, as an international legal person with well-defined state's borders, is the entirely different name than the plain name "Macedonia" as a broader region in the Balkans. The region "Macedonia" that includes part of the Republic of Greece is not a legal person, and cannot be legally relevant since the
"Republic of Macedonia" relates to the state's name as a name of international subject, while the region called Macedonia is not an international person (and hence the names are legally not the same).

The second principle, as we have previously mentioned here is that the name of a State (which is subject to that state's domestic jurisdiction), and even any changes of that name, does not create international legal rights for that state, nor does it impose legal obligations on other states. The International court of Justice in its Judgement delivered on 5th of Dec. 2011 rejected Greek allegation that Macedonian name and its behavior were irredentist and that it had territorial claims against Greece (see ICJ case the FYROM vs Greece (2011)). The Court's rejection of the alleged irredentism was in fact similar in nature as the rejection of the Badinter's Commission (in 1991) of Greek allegations accusing Macedonia for irredentism and territorial claims.

A third important principle that could be derived here is that historical and geographical context of the state's name does not impose any legal obligations on other states and that such historical interpretations and geographical context could not restrict the chosen name of the State. Furthermore, the state's name could not be a subject of a theft or falsification, also state's name may not be imposed, or be given or taken/deprived (by anyone). Similarly, the state's name could not be subjected to any process of external negotiation (s) or any external attempt to regulate it, as was the case with the Macedonian state name. In conclusion, UNSC Res. 817, UNGA $47 / 225$ and UNSC 845 were outside of the legal jurisdiction given to the $\mathrm{UN}$ and its organs by the UN Charter. UNSC Res. 817 related to the mandatory imposition of identity negotiations, even in the phase of admission to UN, was initiation of de-legitimization of a national identity (with an attempt of artificial imputation of "security" dimension) contrary to the UN Charter.

Finally, a fourth principle that we could also derive here is that two or more states cannot have a legal dispute over their state name (s). In the former Yugoslavia, Macedonia had used the name Socialist Republic of Macedonia, and Greece did not objected to the use of that name. Hypothetically, if Macedonia has never applied to the UN membership, this country (Macedonia) would now had the state name originally chosen by its people (who are ethnic Macedonians). Only through a process of UN admission, it was possible to put the Macedonian state in an (illegal) framework were it was subjected to long negotiations and finally forced to change the national name and its constitutional order, in order to satisfy international community and continue with EU and NATO integrations. It should be observed that the international legal identity (the state's name) of a juridical person (a State) exists even without any entrance or participation in membership of any international organization. The legal identity is the fundamental element of legal personality (both internal and international). And as was pointed here, a legal identity is the basic precondition both for the Statehood and the juridical personality of a state. The new definition of a Statehood of 
any state should cover four elements: 1. population, 2. territory, 3. sovereign power, and finally 4. International juridical personality. The forth element (juridical personality) is of crucial importance to third element (sovereign power), and its basic part is the state's (or national) name, as the fundamental part of the juridical capacity for representation and the capacity to contract and exercise other legal functions. So, as we may conclude jus cogens norm of self-determination covers the areas of the rights of State and the human collective rights of people including rights of nations. Self-determination principle from the UN Charter relates to the State's name and the inalienable right of a State and a nation to freely make choice in that matter.

\section{References}

[1] Final Agreement for the settlement of the differences as described in the United Nations Security Council Resolutions 817 (1993) and 845 (1993). Retrieved from https://www.un.org/pga/73/wp-

content/uploads/sites/53/2019/02/14-February-Letter-dated14-February-2019.pdf

[2] UNSCR (07/04/1993) Resolution 817, New member: F. Yug. Rep. of Macedonia. Retrieved from http://unscr.com/en/resolutions/817

[3] Charter of the United Nations

[4] UNGA Res. 47/225 Admission of the State whose application is contained in document $\mathrm{A} / 47 / 876-\mathrm{S} / 25147$ to membership in the United Nations (1993). Retrieved from https://www.un.org/documents/ga/res/47/a47r225.htm

[5] ICJ (1948) Advisory Opinion of International Court of Justice (ICJ) of May 28, 1948. Retrieved from https://www.icjcij.org/files/case-related/3/003-19480528-ADV-01-00-EN.pdf

[6] Henkin, Richard C. Pugh, Oscar Schachter \& Hans Smit, International Law: Cases and Materials 253 (3d ed. 1993).

[7] I. Janev, Legal Aspects of the Use of a Provisional Name for Macedonia in the United Nations System, American Journal of International Law, Vol. 93, No. 1, 1999.
[8] I. Janev, "On the UN's Legal Responsibility for the Irregular Admission of Macedonia to United Nations", PerceptionsJournal of International Affairs, Vol. VII, No. 4, 2002

[9] I. Janev, "On the legal status of Macedonia in the United Nations: A case for Juridical Redress", Political Review 2, 2005.

[10] Vienna Convention on the Representation of States in their Relations with the International Organizations of Universal Character" of March 14, 1975.

[11] I. Janev, D. Petrovic, Legal Mode for Advisory Redress at the International Court of Justice for the Case of Macedonian UN Membership, Review of International Affairs, 2011.

[12] MK News (08/09/2016) After 25 years independenceCountries that recognize Macedonia under its constitutional name. Retrieved from https://mkd-news.com/po-25-godininezavisnost-eve-koi-zemji-ne-priznavaat-pod-ustavnoto-ime/

[13] UNSCR (18/06/1993) Resolution 817, New member: F. Yug. Rep. of Macedonia. Retrieved from http://unscr.com/en/resolutions/845

[14] UN (23/05/1969) Vienna Convention on the Law of Treaties. Retrieved from http://legal.un.org/ilc/texts/instruments/english/conventions/1_ 1_1969.pdf

[15] UN Peacemaker (1995) Interim Accord between Greece and the Former Yugoslav Republic of Macedonia. Retrieved from https://peacemaker.un.org/greecefyrom-interimaccord95

[16] Ministry of Justice of the Republic of Macedonia (2006) Constitution of the Republic of Macedonia. Retrieved from https://okno.mk/sites/default/files/009-USTAV-na-RM.pdf

[17] Macedonian daily "Republika" (15/01/2019) President Ivanov says the Prespa agreement and Albanian language law ratification is brutal violation of the Constitution. Retrieved from https://english.republika.mk/news/macedonia/presidentivanov-says-the-prespa-agreement-and-albanian-languagelaw-ratification-is-brutal-violation-of-the-constitution/

[18] Ekathimerini (NEWS 25. 02. 2019) Public divided in North Macedonia over name deal, poll shows. Retrieved from http://www.ekathimerini.com/238066/article/ekathimerini/new s/public-divided-in-north-macedonia-over-name-deal-pollshows. 